Reprod. Nutr. Dévelop., 1980, 20 (6), 1781-1788.

\title{
Field trials of a method of induction of autoimmune gonad rejection in Atlantic salmon (Salmon salar L.)
}

par Lindsay M. LAIRD, A. R. WILSON, F. G. T. HOLLIDAY *

Department of Zoology, University of Aberdeen,

Tillydrone Avenue, Aberdeen, AB9 2TN, U.K.

* University of Durham, Old Shire Hall, Durham DH1 3HP, U.K.

Summary. Autoimmune gonad destruction was induced in Atlantic salmon of both sexes in trials carried out on fish kept in sea cages on a fish farm. Damage to gonads was only found in fish where the first injection of gonad extract had been given together with Complete Freund's Adjuvant, injections without adjuvant or with carrageenan as an adjuvant were unsuccessful. Length and weight differences between treated and untreated groups of fish were slight at the termination of the experiment.

Results suggest that practical application of this technique would involve injection at an early stage of gonad development and at a higher water temperature $\left(>10^{\circ} \mathrm{C}\right)$ to increase the rate of the primary autoimmune response.

The lesion induced in the salmon testis was compared with that caused by autoimmune destruction of mammalian testis.

\section{Introduction.}

Preliminary experiments have shown that it is possible to induce an autoimmune reaction in the testes of Atlantic salmon and thus destroy the germ cells (Laird et al., 1978). The benefits to the fish farming industry of rearing fish without gonads include:

1. Harvesting of fish is not subject to the constraints imposed by gonad maturity and marketing can take place at the optimum fish size and time of year according to purely economic criteria.

2. The cessation of somatic growth and increased susceptibility to fungal invasion (Richards and Pickening, 1979) associated with gonad maturation could be eliminated.

3. The possibility of improved conversion of food into flesh with no wastage by conversion to gonad material.

Other methods which have been proposed for the sterilization or modification of gonads in farmed fish involve surgical gonadectomy or the use of steroid hormones. Surgical gonadectomy for farmed salmonids has been successfully carried out (Brown and Richards, 1979), with low mortalities resulting. However the operation takes a minimum of $90 \mathrm{sec}$, fish less than $25 \mathrm{~cm}$ length are unsuitable and in Britain may only be performed on farms by veterinary surgeons. 
Treatment of fish with sex steroid hormones has been used with two aims : complete sterilisation or sex reversal. Encouraging results for sex reversal have been obtained by Johnstone et al. $(1978,1979 a$ and $b)$ by the administration to fry, in the dief of $17 \beta$-oestradiol or $17 \alpha$-methytestosterone. These workers established minimum time periods for feeding steroids : shorter periods resulted in the production of hermaphrodites. Less encouraging results were obtained by Jalabert ef al. (1975) and Goetz et al. (1979) suggesting that for successful results a narrow range of treatment conditions exist. Johnstone ef al. (1978) showed adverse conditions to be less tolerated by treated fish than by untreated. Growth depression which occurred during treatment was made up later. One of the aims of steroid treatment is to produce functional males which are genetic females and cross them with normal females to produce all female offspring. Female salmon on average mature later than males, but, with Atlantic salmon, may mature as grilse and all female populations grow more slowly than mixed populations. Because hormone treatment of a batch of fry involves the treatment of genetic males and females to make all male or all female populations it is difficult to assess which fish are normal and which are sex-reversed.

A proportion of sterile fish are produced by hormone treatment (Jalabert et al., 1975) but there has, so far, been no reliable production of a complete batch of sterile fish.

Following the preliminary experiment, field trials were designed to test the following :

1. If results obtained under laboratory conditions could be repeated in field conditions, using older fish than in the previous experiment;

2. If female fish could respond to injection ;

3. The effects of two adjuvants on the fish, both when injected alone and with gonad extract ;

4. The effects of different injection schedules ;

5. If growth of treated fish varied significantly from untreated ones.

\section{Materials and methods.}

The experiments took place on a commercial fish farm; Atlantic salmon (approximate mean weight $750 \mathrm{~g}$ ) of 2 years freshwater and 10 months seawater age were selected for injection. They were kept in a floating cage and fed dry pelleted diet according to the normal routine of the farm. Feeding was observed to continue normally on the day following each treatment. Water temperatures for March averaged $6.6^{\circ} \mathrm{C}$

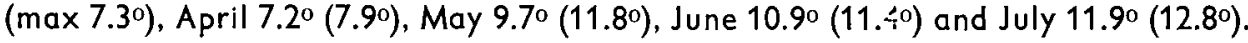

Injections were carried out according to the schedule given in table 1 . The following materials were used in injections :

1) Sterile 0.85 p. 100 saline.

2) Gonad extract. - Testes from maturing (spermatid stage) salmon and ovaries from immature (previtellogenic) female salmon (to avoid yolk contamination) were removed from newly killed Atlantic salmon and stored in liquid nitrogen until half an hour prior 
TABLE 1

Injection schedules

\begin{tabular}{|c|c|c|c|c|c|c|c|}
\hline No of the group ... & 1 & 2 & 3 & 4 & 5 & 6 & 7 \\
\hline No of fish ......... & 50 & 50 & 50 & 50 & 150 & 150 & 150 \\
\hline Treatment (day 0) .. & & $0.2 \mathrm{ml} \mathrm{S}$ & $\begin{array}{l}0.2 \mathrm{ml} \mathrm{s} \\
+-C F A\end{array}$ & $\begin{array}{l}0.2 \mathrm{ml} \mathrm{s} \\
+\mathrm{C}\end{array}$ & $\begin{array}{l}0.2 \mathrm{ml} \mathrm{S} \\
+\mathrm{G}\end{array}$ & $\begin{array}{l}0.2 \mathrm{ml} \mathrm{s} \\
+\mathrm{G} \\
+\mathrm{CFA}\end{array}$ & $\begin{array}{l}0.2 \mathrm{ml} \mathrm{S} \\
+\mathrm{G} \\
+\mathrm{C}\end{array}$ \\
\hline \multirow{2}{*}{$\begin{array}{l}\text { Boosters } \\
\text { (Gonad in } \\
\text { saline) }\end{array}$} & 0 & 0 & 0 & 0 & 100 fish & 100 fish & 100 fish \\
\hline & 0 & 0 & 0 & 0 & 50 fish & 50 fish & 50 fish \\
\hline
\end{tabular}

$0=$ No injection ; $\mathbf{G}=$ - Gonad extract ; $\mathbf{S}==$ Saline ; $\mathrm{CFA}=$ = Complete Freund's Adjuvant ; C. Carrageenan.

to injection. They were then removed from the liquid nitrogen and allowed to thaw at air temperature. When thawed they were washed with saline to remove excess blood and ground through a fine stainless steel mesh sieve $(2.5 \mathrm{mesh} / \mathrm{mm})$ to form a $50 \mathrm{p} .100$ solution with saline. Male and female gonad extract was mixed together for injection.

3) Adjuvants. - (a) Complete Freund's Adjuvant (CFA), (b) Carrageenan X52 Aubygel batch 3557 ... Both adjuvants were mixed $50 / 50$ by volume with the appropriate material for the required injection.

Injections were carried out using $2 \mathrm{ml}$ disposable syringes with 23 gauge needles. These were loaded prior to the capture of the fish, which were removed from the pen by hand net and anaesthetised in a 25 ppm solution of benzocaine. Injections were performed intraperitoneally, the injection site being anterior to the anus and to one side, batch by batch : i.e. all fish for one treatment were injected before another was begun. Each fish was injected with $0.2 \mathrm{ml}$ material, containing approximately $0.1 \mathrm{~g}$ (wet weight) gonad extract.

As all fish were to be kept in a single cage, the different treatments were distinguished by differential marks applied by freeze-branding using liquid nitrogen to cool the brand in the method described by Mighell (1969).

When the first injections were given, time did not permit the weighing and measuring of the fish. However this was carried out at all subsequent injection times and at the time of assessment of the results of the trials. At this last sample, five fish were removed from each treatment, killed, opened by a ventral, longitudinal incision and the gonads removed and preserved in 10 p. 100 buffered formol saline.

In the laboratory the fixed gonad material was embedded in paraffin wax and sections cut at $6 \mu \mathrm{m}$. Staining was by haematoxylin and eosin.

\section{Results.}

Lengths and weights are shown in table 2. There were few significant differences noted : that of May is not found in June and vice versa. 
TABLE 2

Lengths and weights of groups of fish during the trials (Group reference numbers as in table 1)

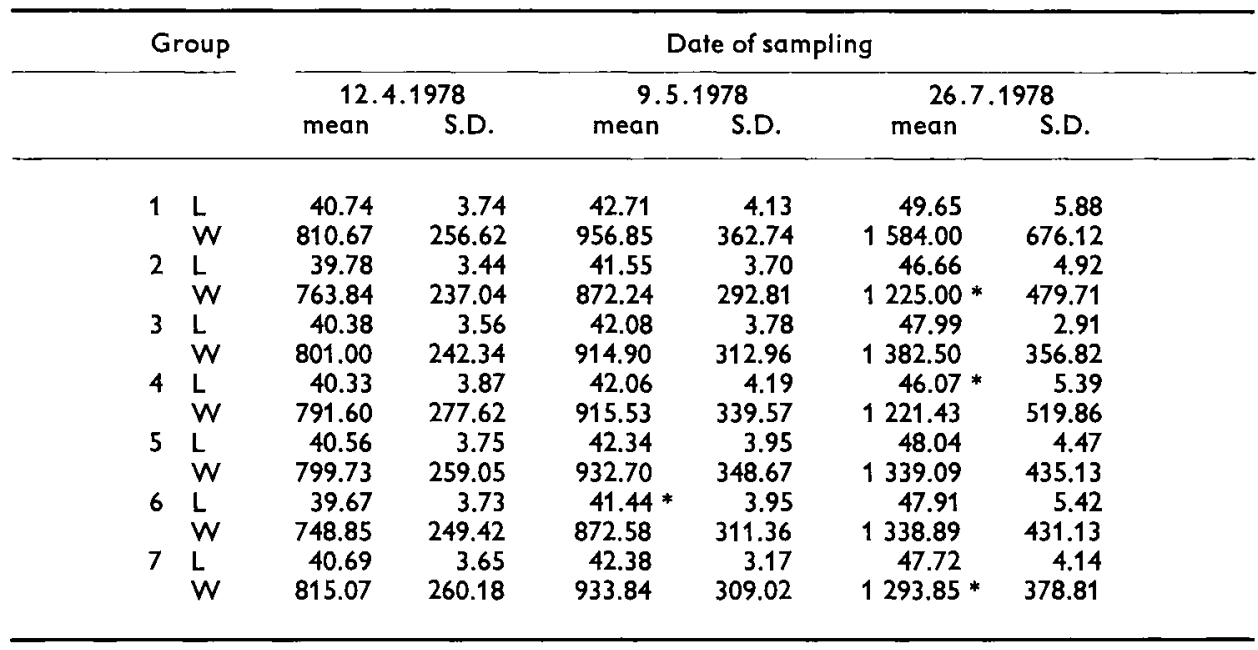

L Length (cms), W Weight (gms).

* Denotes points where data for experimental fish significantly different from the control untreated fish (Group 1) ( $p<0.05)$.

With the exception of one female fish injected with CFA alone which had a small granuloma on the surface of one of the ovaries, the only groups to show reactions in the gonads were those injected with gonad extract plus CFA. It was not possible, owing to fading of the last mark applied, to distinguish those fish which had two and three injections. Of these, all males showed a degree of reaction in both testes, varying from near complete obliteration of normal gonad tissue to a granuloma on the surface of the testis penetrating inwards along the lobule margins. This latter reaction was observed in the more mature animals, the overall impression being that the injections had been carried out at too late a stage of development in those fish which whould have matured as grilse. The testes of the less mature fish are shown in plate 1, and more mature fish in plate 2, and indicate that an active response was still taking place, with the replacement of normal germ tissue by granular connective tissue. Lymphocytes can be seen

Salmon gonads after injection with gonad extract and CFA

PLATE 1. - Immature testis showing infiltration of lymphocyles between tubules from granuloma. $\times 150$.

PLATE 2, - Testis at spermatid stage of development with surface granuloma and inter-lobular inflitiation. $\times 100$.

PLATE 3. - Ovary with surface granuloma penetrating between oocytes. $\times 100$.

PLATE 4. - Posterior part of ovary occluded with granuloma. $\times 50$.

All tissues stained with haematoxylin and eosin. 
(3) - 30 \% 110

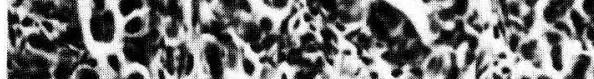

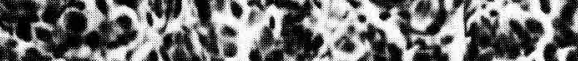

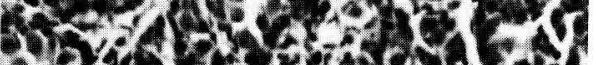

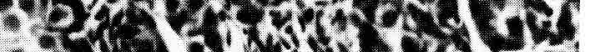

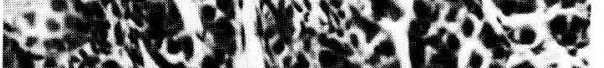
2 .

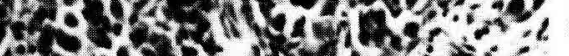

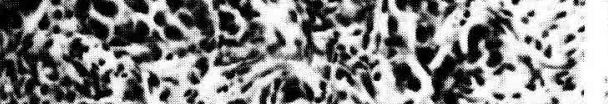

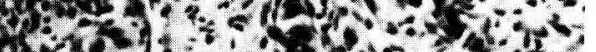

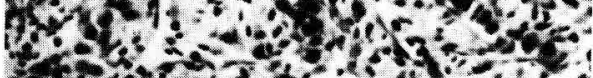

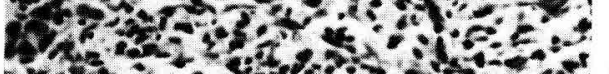

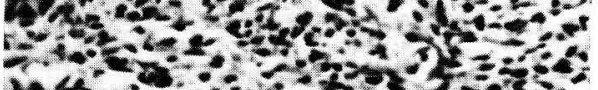
C.6.

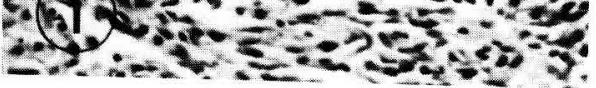

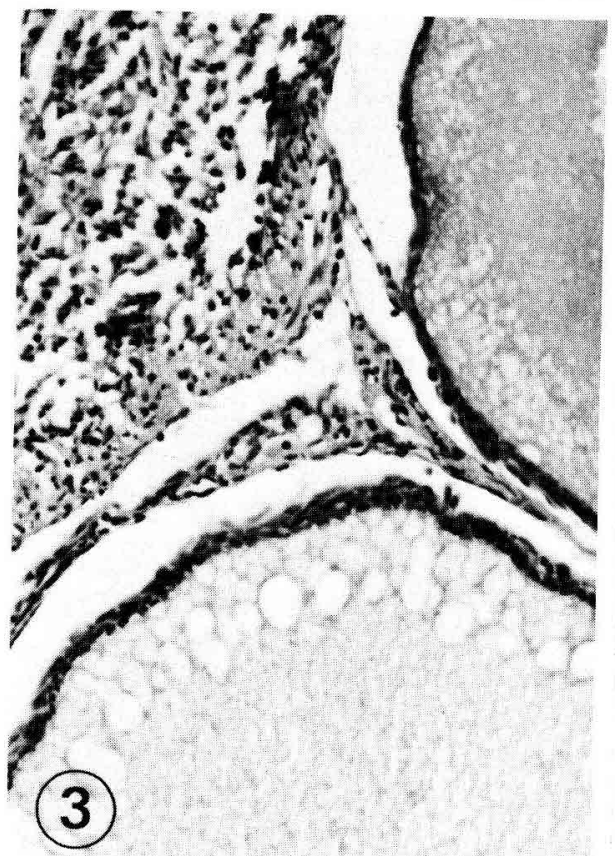

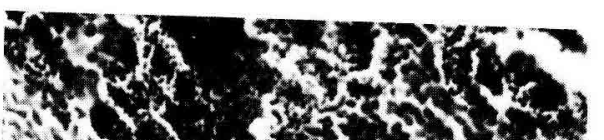

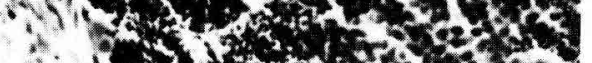

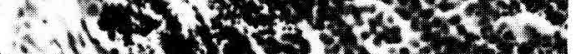
$\because N$ of 'vin

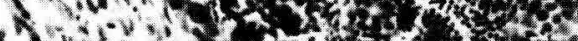

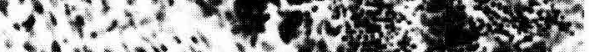
* ve - in s. $e^{2}, z^{2}+x^{2}$

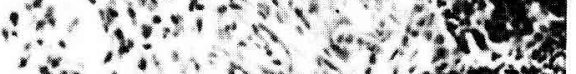

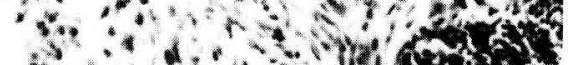

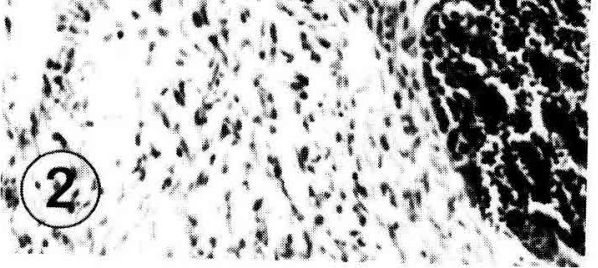

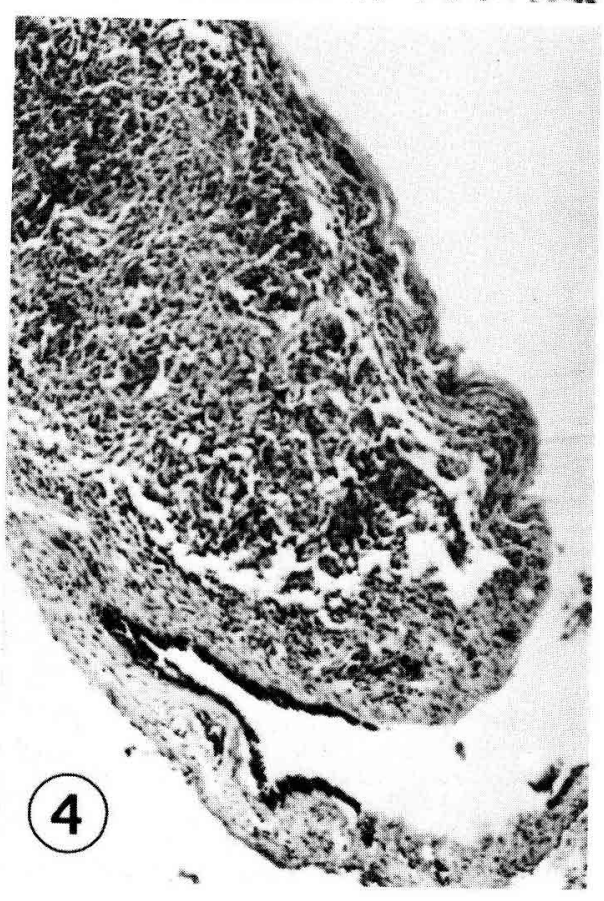


between tubules, the invasion being carried out from a « front 》 of tissue. It is clear that in all these fish the testicular rejection was proceeding actively at the time of sampling. Some male fish which had received one injection of gonad extract and CFA showed similar reactions to those which had received follow-up injections. One of the largest fish sampled, length $55.3 \mathrm{~cm}$, weight $1650 \mathrm{gm}$, condition factor 0.98 had a highly active testicular lesion.

Plates 3 and 4 show the effects on the ovary of injection of gonad and CFA with one or two follow-up injections. Effects were only noted on immature ovaries. Surface granulomas (plate 3) were the most noticeable feature with cells penetrating inwards between oocytes. An aggregation of leucocyles and a proliferation of fibrous tissue around the pre-vitellogenic oocytes can be seen : it seems that more developed yolky oocytes present an impenetrable barrier to invading tissue. Plate 4 shows the posterior end of the ovary in transverse section : in a normal fish this appears as a lacuna and fills with oocytes at a later stage, in this case it is occluded with granular, fibrous tissue.

\section{Discussion.}

The lesion in mammals produced by immunological damage has been described by many authors including Delaunay and Voisin (1952), Freund ef al. (1953) and Bishop and Carlson (1965). A recent review (Setchell 1978) concluded that « Immunological aspermatogenesis apparently results when the immune system is exposed to testis antigen and a granulomatous reaction : the latter may result from the adjuvant or other causes ».

Salmonid testes differ markedly in position and structure from those of mammals. In salmon they are paired organs positioned along the dorsal wall of the body cavity below the kidney, with the ovaries in females being similarly positioned. The structure of the testis in precociously mature male Atlantic salmon parr was described by Jones and Orton (1940). Regions of the gonad are less clearly defined than in the mammal, there are no accessory glands and there is no corresponding structure to the rete testis, the region of the mammalian testis where the immunological reaction begins following injection with testis homogenate and CFA.

The injections producing the response described in this paper were given intraperitoneally (IP) leaving $0.2 \mathrm{ml}$ of injected material inside the peritoneal cavity. This simple and convenient technique is the most commonly used method of injecting fish. However, in mammals injection to produce autoimmune testicular damage has usually been performed intracutaneously or intramuscularly.

The lesions described here differ from those described for mammals in that they appear to progress into the gonad from a granuloma forming on the outer connective tissue surface of the gonad rather than from the internal mature parts of the gonad. It is probable that this granuloma is instituted by macrophages from the body cavify. A further noticeable difference between the reaction in fish and that in mammals is that fish testes are able to respond at an earlier stage of germ cell development : destruction proceeded in testes where the germ cells had only reached the primary spermatocyte stage of development. 
It has been shown that, as yet, no foolproof method exists for sterilisation of large numbers of fish. The results obtained so far on induction of autoimmune gonad destruction are sufficiently encouraging to believe that a technique could be evolved by which salmonids could be sterilised on farms. However, the lack of data on salmonid immune systems in general and particularly on automimune reactions in fish means that much more experimental work is necessary before the fechnique can be used commercially.

\section{Conclusions.}

1. Immune rejection of gonad can be induced in Atlantic salmon kept under farmed conditions.

2. It was shown that female salmon are capable of a response to injected gonad material + CFA.

3. Autoimmune rejection of gonad is only stimulated by injection of gonad extract with CFA.

4. Owing to failure of the marking technique it is not possible to distinguish between fish which had two and three injections. However, all fish with two or more injections had reacted to the injection, suggesting that the third injection may have been unnecessary.

5. Only small differences in growth rates were elicited by the treatment.

6. The reaction induced in this experiment is slow and two major improvements can be suggested for practical applications :

a) Injections should be carried out at warmer water temperatures. The primary immune response in teleosts is temperature dependent : being more rapid if initiated at higher temperatures.

b) Injections should be carried out at an earlier stage of gonad development. In both sexes the reaction appeared impeded by the size and, in the female, the structure of the gonad.

Taking these factors into account it is suggested that Atlantic salmon should be treated at or near the time of smolt transfer to sea water.

Reçu en décembre 1979

Accepté en mai 1980.

Acknowledgements. - We should like to thank the Highland Trout Company, South Uist, for supplying fish, facilities, help and encouragement. Dr. I. G. Priede, Dr. A. Pike and Dr. C. Spray assisted with field work and Mr. A. Lucas, Mrs. B. Smith and Mr. H. Watt provided technical and photographic support : we are very grateful to all of them. Dr. Laird was financed by the Nuffield Foundation : extra field expenses were provided by the National Research Development Corporation.

Résumé. Il a été procédé à des essais de stérilisation de mâles et de femelles, par la méthode d'immuno-réjection, chez le saumon atlantique élevé en pisciculture (cages en mer). Les lésions dans les gonades ont été trouvées seulement chez les poissons ayant reçu 
lors de la première injection un mélange d'extrait de gonades et d'adjuvant de Freund complet ; un traitement sans adjuvant ou utilisant l'adjuvant Carrageenan X52, ne donne aucun résultat. A la fin de l'expérimentation, les différences dans les longueurs et les poids, entre animaux traités ou non, sont faibles.

Les résultats suggèrent que pour l'application pratique de cette technique il convient d'effectuer l'injection dans les premiers stades de développement des gonades et à une température plus élevée que dans nos essais $\left(>10^{\circ} \mathrm{C}\right)$ si on veut obtenir une augmentation du nombre des réponses de réjection immunitaire.

Les lésions induites dans les testicules du saumon sont comparées à celles causées par destruction auto-immunitaire dans les testicules de Mammifères.

\section{References}

BISHOP D. W., CARLSON G. L., 1965. Immunologically induced aspermatogenesis in Guinea pigs. Ann. N. Y. Acad. Sci., 124, 247-266.

BROWN L. A., RICHARDS, R. M., 1979. Surgical gonadectomy of fish : A technique for veterinary surgeons. Vet. Rec., 104, 215.

DELAUNAY A., VOISIN G. A., 1952. Sur les lésions testiculaires provoquées chez le coabye et chez le rat par l'endotoxine typhoïque. C. R. Acad. Sci. Paris, 234, 158-160.

FREUND J., LIPTON M. M., THOMPSON G. E., 1953. Aspermatogenesis in the guinea pig induced by testicular tissue and adjuvants. J. exp. Med., 97, 711-726.

GOETZ F. W., DONALSON E. M., HUNTER G. A., DYE H. M., 1979. Effects of estradiol-17ß and $17 \alpha$-methyltestosterone on gonadal differentiation in the Coho salmon Oncorhynchus Kisutch. Aquaculture, 17, 267-278.

HOLLIDAY F. G. T., LAIRD L. M. Histological changes in the gonad associated with the reproductive cycle of the Atlantic salmon (Salmo salor L.) (In prep.).

JALABERT B., BILLARD R., CHEVASSUS B., 1975. Preliminary experiments on sex control in trout : production of sterile fishes and simultaneous self-fertilizable hermaphrodites. Ann. Biol. onim, Biochim. Biophys., 15, 19-28.

JOHNSTONE R., SIMPSON T. H., YOUNGSON A. F., 1978. Sex reversal in salmonid culture. Aquoculture, 13, 115-134.

JOHNSTONE R., SIMPSON T. H., YOUNGSON A. F., WHITEHEAD C., 1979a. Sex reversal in salmonid culture. Part. II. The progeny of sex-reversed rainbow trout. Aquaculture, 18, 13-19.

JOHNSTONE R., SIMPSON T. H., WALKER A. F., 1979b. Sex reveral in salmonid culfure. Part III. The production and performance of all-female populations of brook trout. Aquaculture, 18, 241-252.

JONES J. W., ORTON J. H., 1940. The paedogenetic male cycle in Salmo salar L. Proc. roy. Soc. Lond. (B), 128, 485-499.

LAIRD L. M., ELLIS A. E., WILSON A. R., HOLLIDAY F. G. T., 1978. The development of the gonadal and immune systems in the Atlantic salmon (Salmo salor L.) and a consideration of the possibility of inducing autoimmune destruction of the testis. Ann. Biol. anim. Bioch. Biophys., 18, 11011106.

MIGHELL J. L., 1969. Rapid cold-branding of salmon and trout with liquid nitrogen. J. Fish. Res. Bd Can., 26, 2765-2769.

RICHARDS R. H., PICKERING A. 1978. Frequency and distribution patterns of Saprolegnia infections in wild and hatchery reared brown trout Salmo truffa (L.) and char Salvelinus alpinus (L.). J. Fish Dis., 1, 69-82.

SETCHELL B. P., 1978. The mammalian testis. Paul Elek, London. 